Article

\title{
Towards Improving the Durability and Overall Performance of PV-ETICS by Application of a PCM Layer
}

\author{
Dariusz Heim ${ }^{1, *}\left(\mathbb{D}\right.$, Anna Wieprzkowicz ${ }^{1}{ }^{\mathbb{D}}$, Dominika Knera ${ }^{1} \oplus$, Simo Ilomets ${ }^{2}$, Targo Kalamees ${ }^{2}$ and \\ Zdenko Špitalský ${ }^{3}$ (I) \\ 1 Department of Environmental Engineering, Lodz University of Technology, 90924 Lodz, Poland; \\ anna.wieprzkowicz@p.lodz.pl (A.W.); dominika.knera@p.lodz.pl (D.K.) \\ 2 Department of Civil Engineering and Architecture, Tallinn University of Technology, 19086 Tallinn, Estonia; \\ simo.ilomets@taltech.ee (S.I.); targo.kalamees@taltech.ee (T.K.) \\ 3 Polymer Institute, Slovak Academy of Sciences, 84541 Bratislava, Slovakia; zdeno.spitalsky@savba.sk \\ * Correspondence: dariusz.heim@p.lodz.pl; Tel.: +48-42-6313920
}

check for

updates

Citation: Heim, D.; Wieprzkowicz,

A.; Knera, D.; Ilomets, S.; Kalamees,

T.; Špitalský, Z. Towards Improving

the Durability and Overall

Performance of PV-ETICS by

Application of a PCM Layer. Appl. Sci.

2021, 11, 4667. https://doi.org/

10.3390/app11104667

Academic Editor: Jorge de Brito

Received: 4 May 2021

Accepted: 18 May 2021

Published: 19 May 2021

Publisher's Note: MDPI stays neutral with regard to jurisdictional claims in published maps and institutional affiliations.

Copyright: (c) 2021 by the authors. Licensee MDPI, Basel, Switzerland. This article is an open access article distributed under the terms and conditions of the Creative Commons Attribution (CC BY) license (https:/ / creativecommons.org/licenses/by/ $4.0 /)$.
Featured Application: The developed En-ActivETICS responds to the growing interest in Building Integrated Photovoltaics. Even for certain limitations, results may have practical applications and effects on the safety and durability of the installation. The proposal to improve the solution through the PCM application is one of the ways to solve the overheating problem in extreme temperatures.

Abstract: The main goal of the paper was to numerically analyse the risk of overheating of the Energy Activated External Thermal Insulation Composite System (En-ActivETICS) as an example of Building Integrated Photovoltaics (BIPV). The analyses were conducted with the coupled power flow method (thermal and electrical) for 20 European cities. All locations were analysed considering the local climate in the context of building performance simulation as well as electricity production. The obtained results allowed for the determination of the risk of overheating, which can influence system durability, accelerated thermal ageing, and overall performance. It was revealed that the risk of overheating above $80{ }^{\circ} \mathrm{C}$ is possible in almost all locations; however, the intensity considerably differs between southern and northern Europe. The effect of latent heat storage for better thermal stabilization and overall performance was determined numerically for all locations. Finally, the improved solution with a phase change material (PCM) layer beside the PV panel was proposed individually for specific climatic zones, considering the required heat capacity. The maximum panel temperature for improved En-ActivETICS does not exceed $85^{\circ} \mathrm{C}$ for any location.

Keywords: building facade; external insulation; building integrated PV; solar energy; thermal inertia; overheating; climate classifications

\section{Introduction}

Today, a Building Integrated Photovoltaic (BIPV) installation, mounted on roofs and facades, can be considered as one of the most justified on-site renewable electricity generation technologies. Typical systems of photovoltaics integrated with or applied to building materials were widely analysed and described in the context of simulation and monitoring [1]. Most of the currently used BIPV facade systems are an alteration of various rain screen cladding façades [2], curtain walls [3], spandrel panels [4] or shading systems [5]. Such systems are applied mainly in non-residential and public buildings, playing a representative role. In the case of residential buildings, BIPV mainly takes the form of shingles, slate, tiles or standard modules mounted on the roof [6]. For specific geographical localizations and weather conditions, it was proven that electricity from roof-integrated PV can significantly contribute to the improvement of the overall energy performance by reduction of the annual energy consumption in new [7] and retrofitted houses [8]. Nevertheless, the 
development of economically viable technology for photovoltaics integrated with external walls is still a challenge [9]. The newly developed PV system integrated with a wall [10] as described and analysed in this article can be considered as a technology for future use in the residential sector, facing the challenges mentioned above.

Energy Activated External Thermal Insulation Composite System (En-ActivETIS) is an easy-to-apply, wall-integrated structure based on the well-known ETICS system used for new buildings and building renovations [11]. Unlike typical ETICS, a flexible photovoltaic is applied instead of the existing cement plaster. Single panels can be combined into sections in different arrangements. The proposed technology is an original solution that combines the benefits of a typical well-insulated wall with a photovoltaic built into the building. The limitations in the design of the system include the total area of the walls as well as the size and configuration of the windows. Corresponding to [12], the problem of overheating has been identified as the cause of the decline in energy conversion efficiency [13], mechanical stresses [14], electrical damage [15] and general degradation of the system [16]. The influence of temperature on the production of electricity from photovoltaics was investigated in different applications. As determined by [17], for a multicrystalline silicon photovoltaic module, $1000 \mathrm{~h}$ exposure at $85{ }^{\circ} \mathrm{C}$ and $85 \%$ relative humidity reduces the average normalized maximum power by $10 \%$. In the case of open-rack panels, such exposure means $>100$ years in Munich, 25-50 years in Miami and 6-11 years in Riyadh [18]. Nevertheless, for a poorly ventilated BIPV, the risk of panel overheating is supposed to be significantly higher than in the case of free-standing installations. A subsequent challenge for the insulation layer is the thermal degradation of expanded polystyrene, which is widely used in ETICS. Mehta et al. [19] examined various types of expanded polystyrene and noticed that the polymer spheres collapse when exposed to elevated temperatures around $110-120{ }^{\circ} \mathrm{C}$. Subsequent studies were carried out for expanded graphite polystyrene [20], which is now commonly used in new buildings. It was found that in direct sunlight and temperatures higher than $85^{\circ} \mathrm{C}$, grey polystyrene is destroyed.

As En-ActivETICS is designed as a technological solution without ventilation of the internal surface, there is a high risk of overheating, thermal stresses and mechanical damage in the interstitial joints. One of the main challenges is protection from the possibility of overheating of the external layers (PV panel, adhesive and reinforcing mesh) and the decrease of a large temperature difference between the area covered with standard and activated ETICS. Due to differences in colour and structure of the outer layer, the surfaces may differ significantly in solar absorptivity. One of the ideas of how to stabilize the temperature of a PV panel is to increase the thermal inertia of the layer between it and the thermal insulation [21]. A high latent heat capacity layer consisting of phase change material (PCM) is a promising solution if it is properly sized [22]. The construction of the external PCM layer is a further development of the composite investigated experimentally in the structure of a ventilated façade [23]. Comparison of a cooled and uncooled PV system resulted in the improvement of electrical efficiency obtained experimentally by active cooling up to 12-14\% [24]. Therefore, the reason for using PCM integrated with PV is increasing the efficiency of energy conversion [25]. In the case studied here, the PCM layer is devoted to protecting against overheating above extreme temperatures, above $80^{\circ} \mathrm{C}$, which can cause permanent damage to the PV panel. The main challenge was to determine the layer capacity for a daily cycle of energy storage from solar radiation and then check the effectiveness of the proposed solution during the whole year.

In order to consider all physical processes, the proposed model used in the simulation study takes into account the combined heat and power flow on a building element scale. The simulation model of En-ActivETICS was developed using ESP-r software, applying a special material method [26]. The approach to power flow modelling was based on [27], using the WATSUN-PV model to convert solar radiation into electricity [28]. The analysis was performed for 20 designated locations in Europe (five northern, ten central and five southern). Such analysis under different weather conditions allowed for the investigation of the impact of overheating on the overall system performance and underlined the need 
for protection of the system in extreme weather conditions. The analysis was carried out for a test room with an outer wall partially covered with En-ActivETICS and partially with typical ETICS.

\section{En-ActivETICS as a Proposed Solution for Active External Walls}

\subsection{Construction}

While the final En-ActivETICS concept is still under development, three cases were investigated. Compared with the traditional ETICS wall (Figure 1a), in PV-ETICS, the outer part is covered with a flexible photovoltaic module glued directly to the polystyrene (Figure 1b). In En-ActivETICS, an additional layer of PCM is applied under the PV. The internal structure of the wall, the insulation and construction layer are the same in both cases.

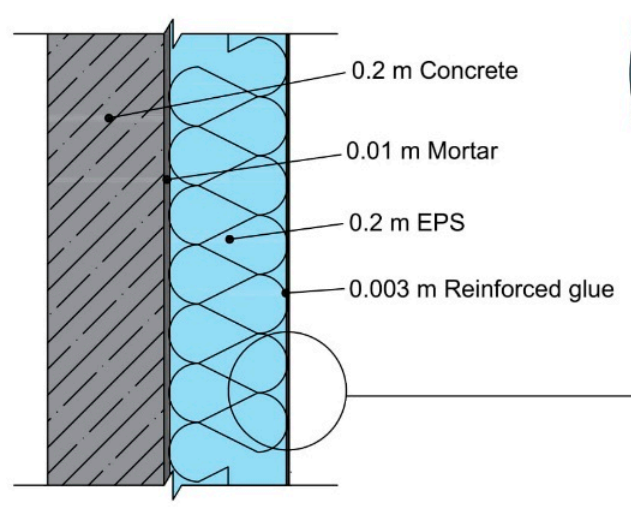

a) ETICS

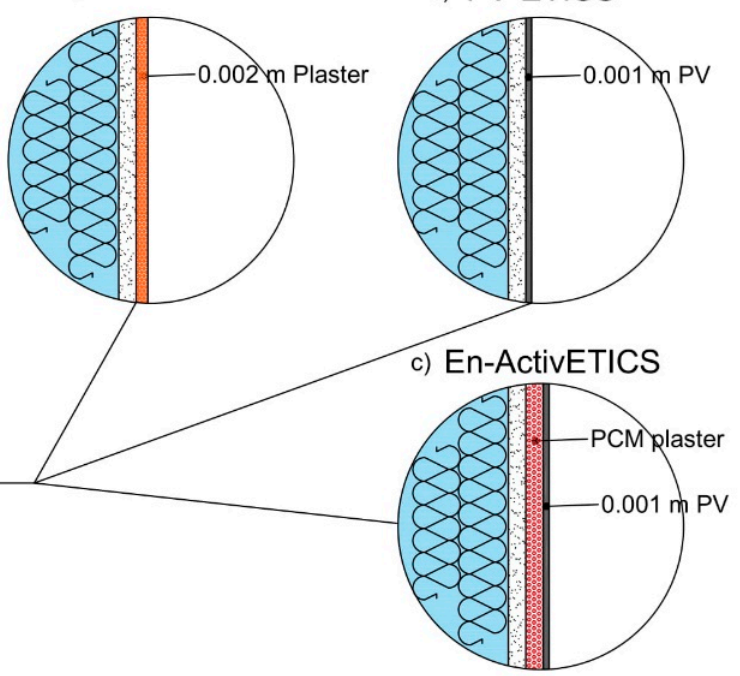

Figure 1. Cross-section of the wall covered with (a) ETICS (b) PV-ETICS and (c) En-ActivETICS.

\subsection{Computational Model}

The thermal performance of the three considered wall cases is mainly influenced by the physical processes taking place on the outer surface of the wall. The difference in the thermal behaviour mainly comes from the varied absorptivity of solar radiation, its photoelectric conversion and the ability for thermal energy storage. It can be assumed that external convection and long-wave radiation as well as the processes of heat conduction are the same. The key parameters of the three considered walls are presented in Table 1.

Table 1. Basic parameters of the three considered cases.

\begin{tabular}{ccc}
\hline Parameter & ETICS & PV-ETICS/En-ActivETICS \\
\hline External surface absorptivity $\alpha[-]$ & 0.22 & 0.84 \\
External surface emissivity $\varepsilon[-]$ & & 0.90 \\
Thermal transmittance of the wall $U\left[\mathrm{~W} /\left(\mathrm{m}^{2} \mathrm{~K}\right)\right]$ & & 0.15 \\
\hline
\end{tabular}

Photovoltaic conversion of solar irradiance incident on the surface of PV cells in ESP-r can be modelled using one of three models: a simple model with constant PV cell efficiency or one-diode circuit models-Kelly's model and WATSUN-PV model. The last one is characterized by the most comprehensive consideration of cell temperature impact on the energy performance of PV panels. Therefore, the WATSUN-PV model is predominantly used to calculate the PV energy performance [8]. In the presented paper, the WATSUN-PV model was also chosen to model the PV panel performance. 
The WATSUN-PV model was implemented into ESP-r and validated in accordance with Mottillo et al. [28] as a consequence of the recommendations of Thevenard [29]. The model considers the impact of PV cell temperature $\left(T_{\text {cell }}\right)$ on the main PV panel electrical characteristics-the short-circuit current $\left(I_{s c}\right)$ and the open-circuit voltage $\left(V_{o c}\right)$-as is presented in Equations (1) and (2).

$$
\begin{gathered}
I_{s c}=I_{s c, \text { ref }} \frac{E_{T, \text { eff }}}{E_{T, \text { ref }}}\left[1+\alpha\left(T_{\text {cell }}-T_{\text {cell }, \text { ref }}\right)\right] \\
V_{o c}=V_{o c, r e f}\left[1-\gamma\left(T_{\text {cell }}-T_{\text {cell }, \text { ref }}\right)\right] \max \left\{\begin{array}{c}
0 \\
1+\beta \ln \left(\frac{E_{T, e f f}}{E_{T, \text { ref }}}\right)
\end{array}\right\}
\end{gathered}
$$

where

$I_{s c, r e f}$-short-circuit current in reference conditions [A]

$V_{o c, \text { ref }}-$ open-circuit voltage in reference conditions [V]

$E_{T, e f f}$-effective irradiance incident on the surface of PV cells $\left[\mathrm{W} / \mathrm{m}^{2}\right]$

$E_{T, r e f}$-irradiance incident on the surface of PV cells in reference conditions, $E_{T, \text { ref }}=1000 \mathrm{~W} / \mathrm{m}^{2}$

$T_{\text {cell }}-\mathrm{PV}$ cell temperature $\left[{ }^{\circ} \mathrm{C}\right]$

$T_{\text {cell, ref }}-\mathrm{PV}$ cell temperature in reference conditions, $T_{\text {cell, ref }}=25^{\circ} \mathrm{C}$

$\alpha$-temperature coefficient of $I_{S C}\left[1 /{ }^{\circ} \mathrm{C}\right]$

$\gamma$-temperature coefficient of $V_{o c}\left[1 /{ }^{\circ} \mathrm{C}\right]$

$\beta$-irradiance coefficient of $V_{o c}[-]$

In the WATSUN-PV model, the maximum power of the PV panel, $P_{m p}$, depends on the short-circuit current and open-circuit voltage, as given by Equation (3):

$$
P_{m p}=I_{m p, r e f} V_{m p . r e f}\left(\frac{I_{s c} V_{o c}}{I_{s c, r e f} V_{o c, r e f}}\right)
$$

where

$I_{m p, r e f}-$ maximum power point current in reference conditions [A]

$V_{m p, r e f}-$ maximum power point voltage in reference conditions [V]

The model of heat transfer with latent heat storage adopted for this study was previously validated [30]. The investigated case was very similar when the PCM layer was semi-exposed to the external environment. Through the definition of the special material properties, latent heat storage is estimated based on the effective heat capacity method [31]. The apparent heat capacity method using the Crank-Nicolson explicit scheme was applied (i.e., the heat capacity was calculated from the node temperature at the previous time step). Despite the highly non-linear dependence of heat capacity and temperature, this function can be substituted by a linear one:

$$
C_{e f f}(T)=a T+b \quad \text { for } \quad T_{M}<T<T_{S}
$$

where

$C_{\text {eff }}$-effective heat capacity [J/kg K]

$T_{M}$-melting temperature $\left[{ }^{\circ} \mathrm{C}\right]$

$T_{S}$ - solidification temperature $\left[{ }^{\circ} \mathrm{C}\right]$

All three considered cases (ETICS, PV-ETICS and En-ActivETICS; see Figure 1) were modelled in ESP-r [32] as multilayer constructions. The latter two cases of the external surface represent the PV modules. In all cases, the southern orientation of the wall was considered with a ground albedo of 0.2 . Calculations were carried out for the whole year using a 5 min time step. 


\subsection{Climate}

The analyses were carried out for 20 selected locations in Europe ( 5 in the north, 10 in the centre and 5 in the south). The 12 cities on the list were chosen as cities in the countries that revealed the highest share of the ETICS market. Moreover, due to the high accessibility of solar energy and its conversion, En-ActivETICS is also popular in 3 southern countries (Spain, Italy, Portugal), where typical ETICS is not useful. In addition, to enable the introduction of En-ActivETICS to new markets, 5 more locations in northern and central Europe were tested. All selected locations are listed alphabetically in Table 2. Locations not selected based on the ETICS market potential were additionally marked with the ${ }^{\text {ne }}$ symbol. Two Köppen-Geiger climate classes are given for each location. The first one represents the classification of the photovoltaic climate, K-G-P [33], while the second one corresponds to the climates developed for simulation analysis of buildings, K-G-S [34].

Table 2. Analysed locations and Köppen-Geiger classifications.

\begin{tabular}{|c|c|c|c|c|}
\hline No & Abbreviation & Country/City & K-G-P & K-G-S \\
\hline 1 & VNA & Austria, Vienna & $\mathrm{DM}$ & $\mathrm{Dfb}$ \\
\hline 2 & MSK & Belarus, Minsk ne & EL & $\mathrm{Dfb}$ \\
\hline 3 & PRG & Czech Republic, Prague & $\mathrm{DM}$ & $\mathrm{Dfb}$ \\
\hline 4 & TLN & Estonia, Tallinn ne & $\mathrm{EL}^{*}$ & $\mathrm{Dfb}$ \\
\hline 5 & HLS & Finland, Helsinki & EL & $\mathrm{Dfb}$ \\
\hline 6 & PRS & France, Paris & $\mathrm{DM}$ & $\mathrm{Cfb}$ \\
\hline 7 & BRN & Germany, Berlin & $\mathrm{DM}$ & $\mathrm{Dfb}$ \\
\hline 8 & $\mathrm{DBC}$ & Hungary, Debrecen & $\mathrm{DM}$ & $\mathrm{Dfb}$ \\
\hline 9 & $\mathrm{ROM}$ & Italy, Rome ne & $\mathrm{DM}^{*}$ & Csa \\
\hline 10 & AMS & Netherlands, Amsterdam ne & $\mathrm{DM}$ & $\mathrm{Cfb}$ \\
\hline 11 & BRG & Norway, Bergen & $E L^{*}$ & $\mathrm{DfC}_{\mathrm{C}}^{*}$ \\
\hline 12 & LDZ & Poland, Lodz & $\mathrm{DM}^{*}$ & $\mathrm{Dfb}$ \\
\hline 13 & LSB & Portugal, Lisbon ne & $\mathrm{DH}$ & Csa \\
\hline 14 & $\mathrm{BCR}$ & Romania, Bucharest & $\mathrm{DM}$ & $\mathrm{Cfb} *$ \\
\hline 15 & BRT & Slovakia, Bratislava & $\mathrm{DM}$ & $\mathrm{Dfb}$ * \\
\hline 16 & MDR & Spain, Madrid ne & $\mathrm{DH}^{*}$ & Bsk * \\
\hline 17 & STK & Sweden, Stockholm & $\mathrm{DL}^{*}$ & $\mathrm{Dfb}$ \\
\hline 18 & GNV & Switzerland, Geneva ne & EM & $\mathrm{DfC}_{\mathrm{C}}^{*}$ \\
\hline 19 & KEV & Ukraine, Kiev ne & $\mathrm{DM}^{*}$ & $\mathrm{Dfb}$ \\
\hline 20 & LND & United Kingdom, London & $\mathrm{DM}^{*}$ & $\mathrm{Cfb}$ \\
\hline
\end{tabular}

Most cities selected for the analysis were classified as $\mathrm{Dfb}-\mathrm{a}$ cold climate without a dry season and with a warm summer, based on the K-G-S classification. Other identified classes for the analysed locations are Dfc (cold climate without a dry season and with a cold summer), $\mathrm{Cfb}$ (temperate climate without a dry season and with a warm summer), Csa (temperate climate with a dry and hot summer) and Bsk (dry and cold steppe climate).

Taking into account the indicators for the K-G-P photovoltaic climate, most locations were classified as DM-temperate with medium irradiation. Scandinavian locations were classified as EL-cold with low irradiation-except for Stockholm, which was classified as DL-temperate with low irradiation. Cities on the Iberian Peninsula were classified as DH—temperate with high irradiation-while Geneva was on the border with EM-cold with moderate radiation.

Figure 2 shows the locations of 20 cities in Europe. For the numerical simulation, hourly data according to the TMY standard [35] (EnergyPlus Weather Data) was used. The statistical analysis of the ambient temperature and solar irradiation for all 20 locations was performed. Comprehensive data is shown in Figures 3 and 4.

The analysis of the ambient temperature is shown in Figure 3. The minimum $\left(\mathrm{T}_{\min }\right)$ and maximum $\left(\mathrm{T}_{\max }\right)$ temperatures were determined for each location. Additionally, the minimum $\left(\mathrm{T}_{\min D A}\right)$ and maximum $\left(\mathrm{T}_{\operatorname{maxDA}}\right)$ average daily temperatures are presented. Moreover, the average daily difference of ambient temperature $\left(\mathrm{T}_{\mathrm{ADD}}\right)$ is given. 
The second parameter that significantly affects the surface temperature is solar radiation. The climatic data were processed to calculate the maximum daily sum ( $\left.\mathrm{E}_{\max }\right)$, and the daily sum of the total solar irradiance on the horizontal surface $\left(E_{D A}\right)$ was averaged.

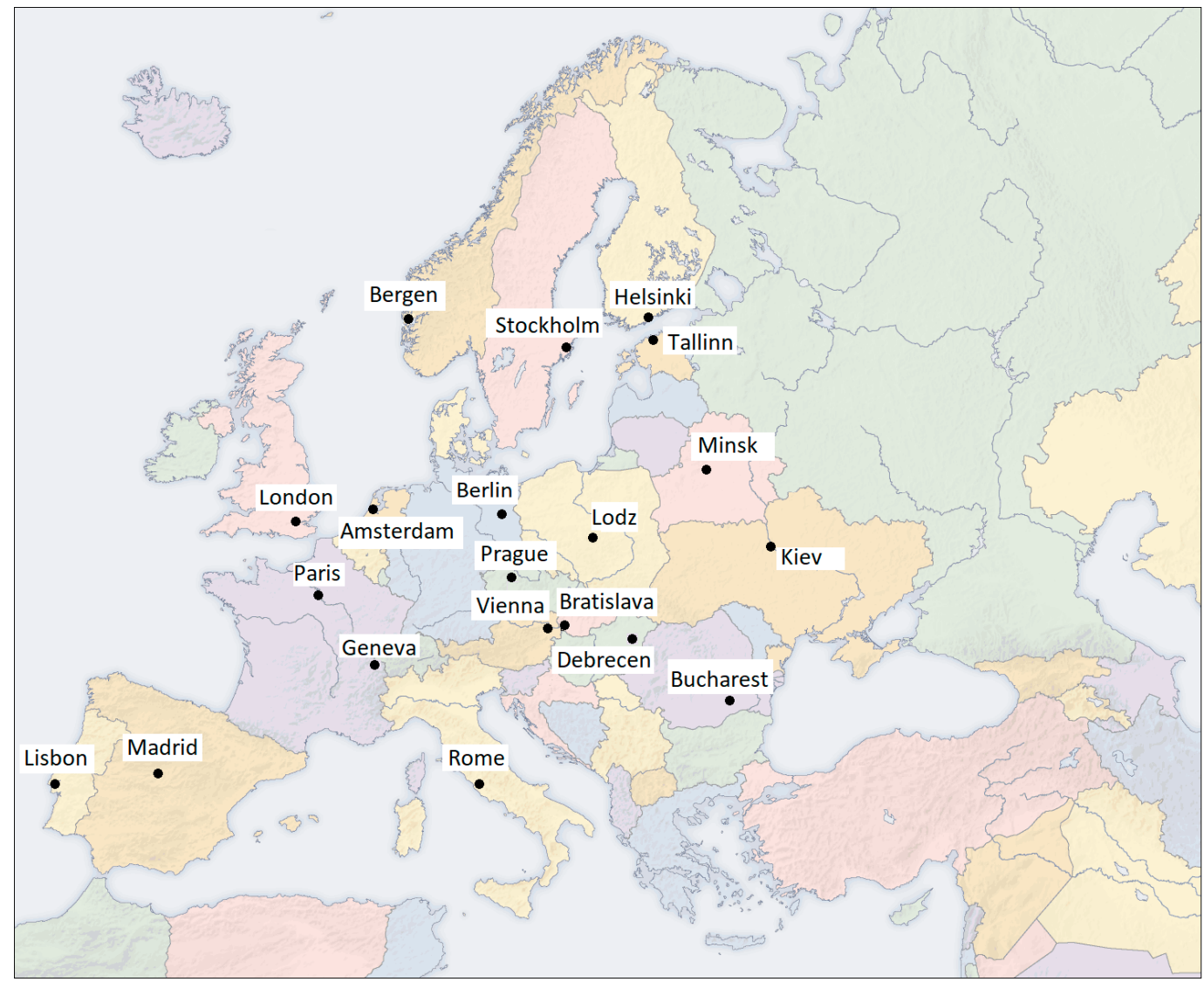

Figure 2. Locations of the cities selected for the analysis.

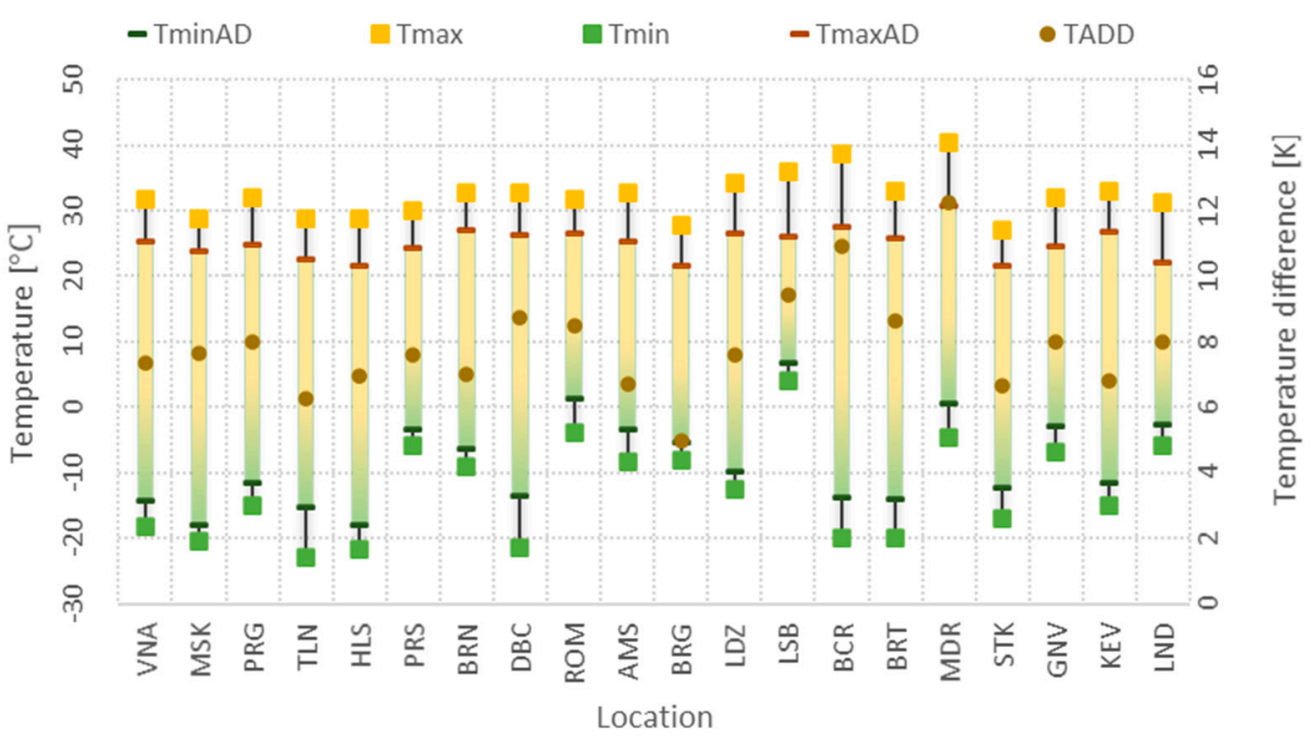

Figure 3. Ambient temperature statistics for analysed locations (see Table 2). 


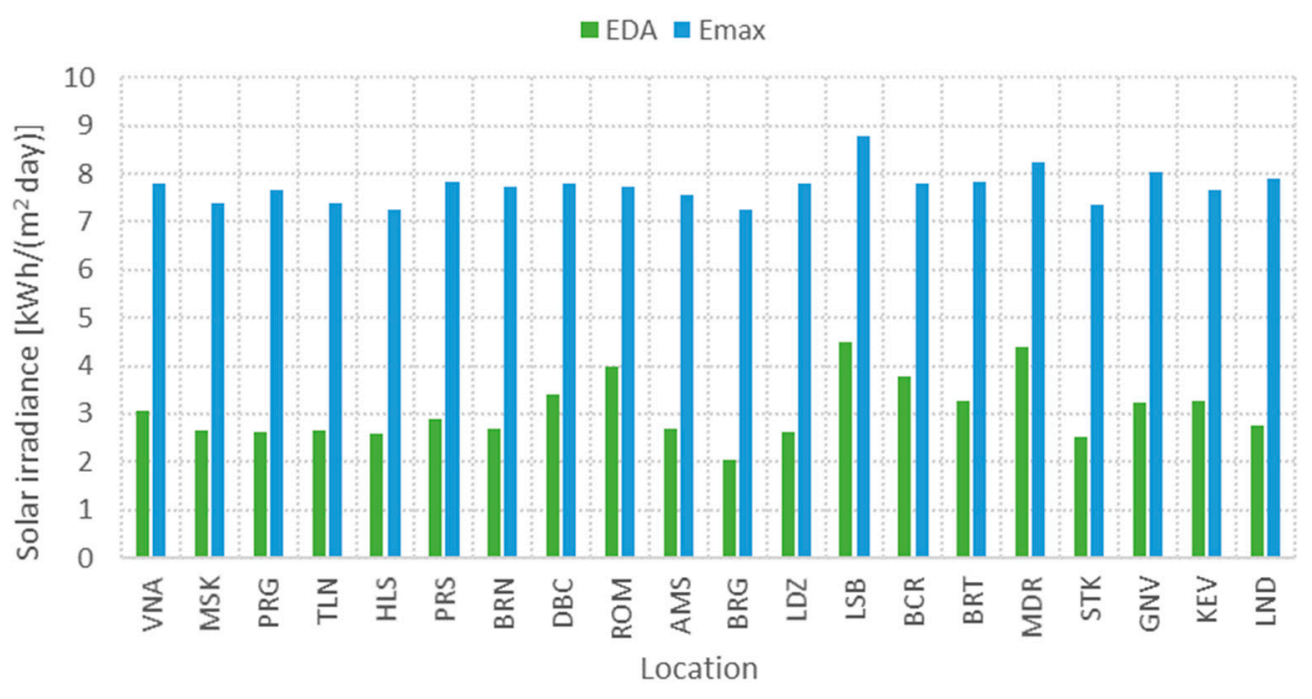

Figure 4. Solar irradiance availability at the horizontal surface for analysed locations.

Comparison of the temperatures shown in Figure 3 revealed that the maximum ambient temperatures occur in Madrid (above $40^{\circ} \mathrm{C}$ ). Madrid has the largest daily difference in ambient temperatures (over $12 \mathrm{~K}$ ). In 5 cities in Scandinavia and Eastern Europe (Minsk, Tallinn, Helsinki, Bergen and Stockholm), the maximum temperature does not reach $30^{\circ} \mathrm{C}$. Cities with the highest extreme temperatures also have maximum daily average temperatures. Minimum temperatures were recorded for Scandinavian cities but also for central Europe (Debrecen, Bucharest and Bratislava). For passive cooling systems working on a $24 \mathrm{~h}$ cycle, the key parameter is the temperature difference between daytime and nighttime $\left(\mathrm{T}_{\mathrm{AAD}}\right)$. The highest values of $\mathrm{T}_{\mathrm{AAD}}$ were noted in Madrid and Bucharest (above $\left.10 \mathrm{~K}\right)$. The minimum value was registered in Bergen (below $5 \mathrm{~K}$ ).

In locations with the highest values of maximum ambient temperature, solar radiation is also very high, giving the highest values of the average daily sum of solar energy available on a horizontal surface (Figure 4). Southern locations in Europe are characterized by the maximum sum of solar radiation on the horizontal plane. The lowest values were recorded for Scandinavian cities.

The highest values of $\mathrm{E}_{\mathrm{DA}}$ index were observed for the cities characterized by the highest values of maximum ambient temperature and high solar radiation (Figure 4). The lowest values were observed for Nordic cities, while the highest were for southern cities.

\section{Initial Investigations and Problem Definition}

This study is devoted to identifying the overheating problem of PV-ETICS during use in different climatic conditions across Europe. The study described in Section 2 (see Figure 3) shows the differences in weather parameters, mainly in the intensity of solar radiation. The initial thermal analyses show that, for selected locations, the thermal behaviour of ETICS and PV-ETICS was determined using a simulation technique. The results of extreme temperatures for both systems are presented in Figure 5. It can be noted that the temperature of traditional ETICS does not exceed $60^{\circ} \mathrm{C}$. On the other hand, the peak temperature of PV-ETICS, which is covered on the outside by a dark PV layer, is over $80^{\circ} \mathrm{C}$ for all locations. For some specific cities like Rome, Bucharest and Madrid, the value is well above $90^{\circ} \mathrm{C}$. It can be concluded that there is a risk of overheating, causing possible destruction of PV panels and limits to service life. Therefore, eliminating this risk is crucial to the proper design of En-ActivETICS, which is the modification of PV-ETICS by PCM application. One of the justified solutions is the implementation of a PCM layer on the inner side of PV panel. The size and material properties of this layer should be initially determined based on the results from, e.g., numerical simulation. The following three-step approach is proposed: 


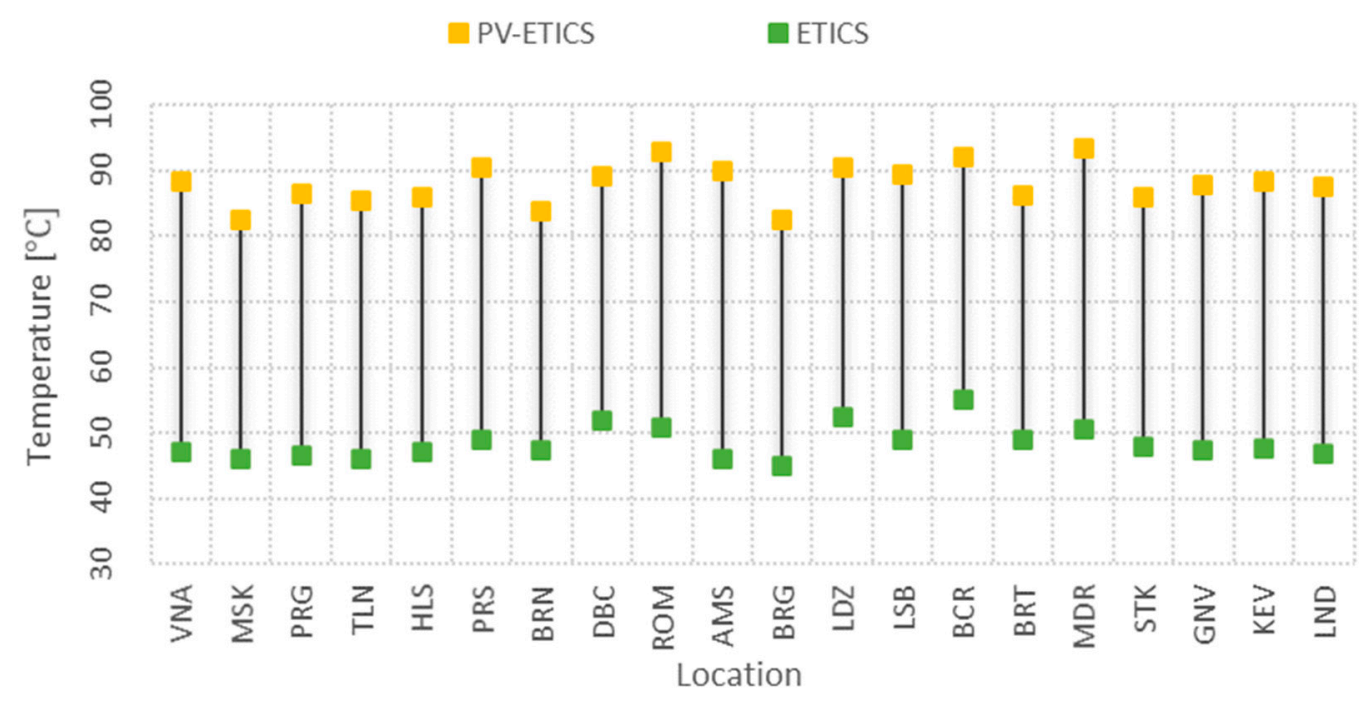

Figure 5. Maximum values of temperature on the external surface of ETICS and PV-ETICS for analysed locations.

Step 1-Determination of the daily average and maximum amount of absorbed solar energy to be stored in the PCM layer:

- determination of the amount of solar energy received by the panel when the temperature is above $80^{\circ} \mathrm{C}$;

- determination of the amount of energy converted into electricity;

- determination of the daily sum of solar energy converted into heat.

Step 2-Determination of required the amount of phase change material as well as the total weight and thickness of the layer.

Step 3-Investigation of the effect of latent heat storage on the temperature of the PV panel through calculation the values of $t 80$ (number of overheating hours when temperature is above $80^{\circ} \mathrm{C}$ ) and DH80 (degree hours of overheating above $80^{\circ} \mathrm{C}$ ) for ETICS and En-ActivETICS.

\section{Results and Discussion}

The first step in the PCM layer design was calculation of the amount of solar energy that needs to be stored. For this purpose, the solar energy incident on the façade was calculated during the time when the PV panel temperature exceeds $80^{\circ} \mathrm{C}$. Using a temperature-dependent model of electricity generation, the values of energy production were calculated. The obtained results were also correlated with the instantaneous values of $\mathrm{PV}$ panel temperature, and the values representative of temperatures above $80^{\circ} \mathrm{C}$ were used for further analysis. It was assumed that part of the solar energy incident on the façade will be transferred into electricity, while the rest will be transferred into thermal energy, causing the PV temperature rise. Since the overheating of the panels above $80^{\circ} \mathrm{C}$ is destructive, it was assumed that the PCM layer should be designed to store this excess energy. Calculation of the average annual productivity of the flexible PV panels used with ETICS revealed that this productivity is at the level of approximately $5 \%$, which means that $95 \%$ of the solar energy affecting the façade should be stored (Figure 6). The values of the amount of energy that should be stored in the PCM layer significantly varied for the selected locations. For 13 locations, the values of energy did not exceed $20 \mathrm{~kW} \mathrm{~h} / \mathrm{m}^{2} / \mathrm{a}$, while four of them had values above $50 \mathrm{~kW} \mathrm{~h} / \mathrm{m}^{2} / \mathrm{a}$. The highest need for solar energy storage was registered in Madrid, Lisbon, Rome and Bucharest, which were also characterized by the highest solar irradiance availability at the horizontal surface. 
OSolar energy on the facade $\quad$ Solar energy to be absorbed Productivity

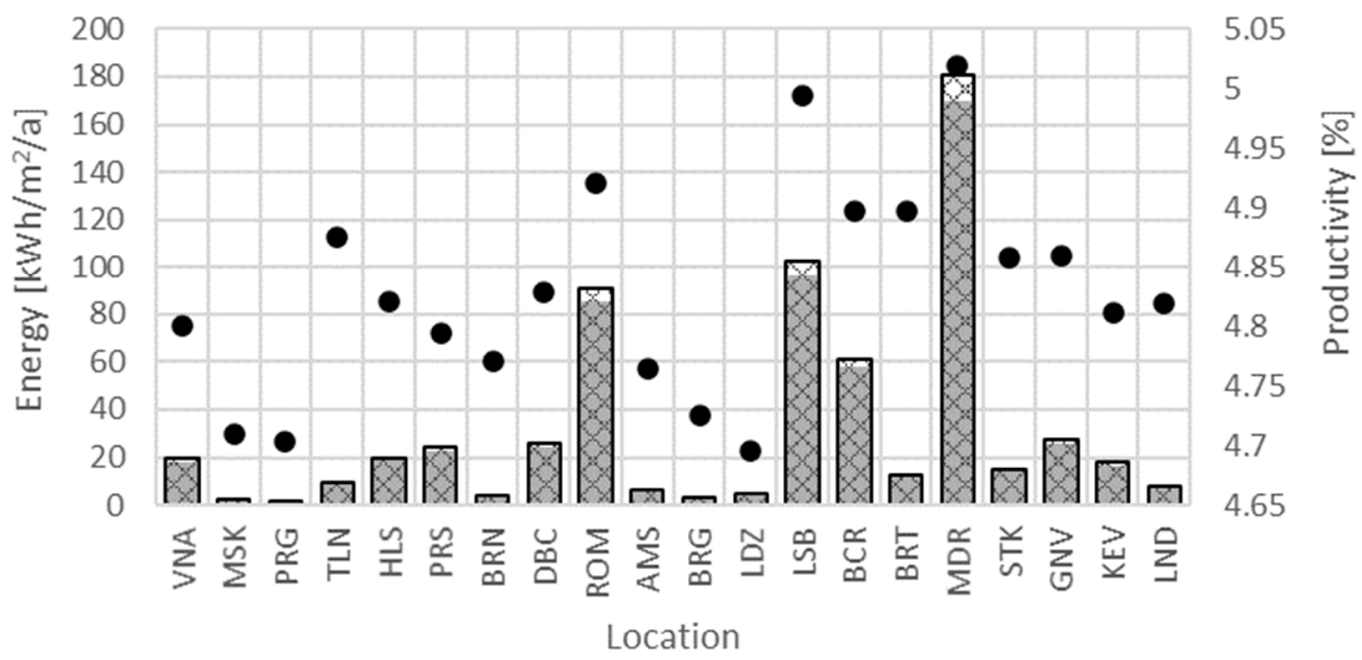

Figure 6. Solar energy incident on the façade, calculated as the potential to be absorbed in the PCM layer.

Analysis of the daily values of the amount of solar energy to be absorbed in the PCM layer revealed that for most locations the problem of PV panel overheating lasts for less than 20 days during the year, and despite high maximum values for most of the time, calculated values oscillate on the lower levels (Figure 7). Because of this, it was assumed that the thickness of the PCM layer should be designed for the amount of material needed to absorb the average value of solar energy. The daily values were used in the further analysis to ensure the daily cycle of energy absorption and release (active thermal capacity).

\section{Max energy $\square$ Average energy $\quad$ Number of overheating days}

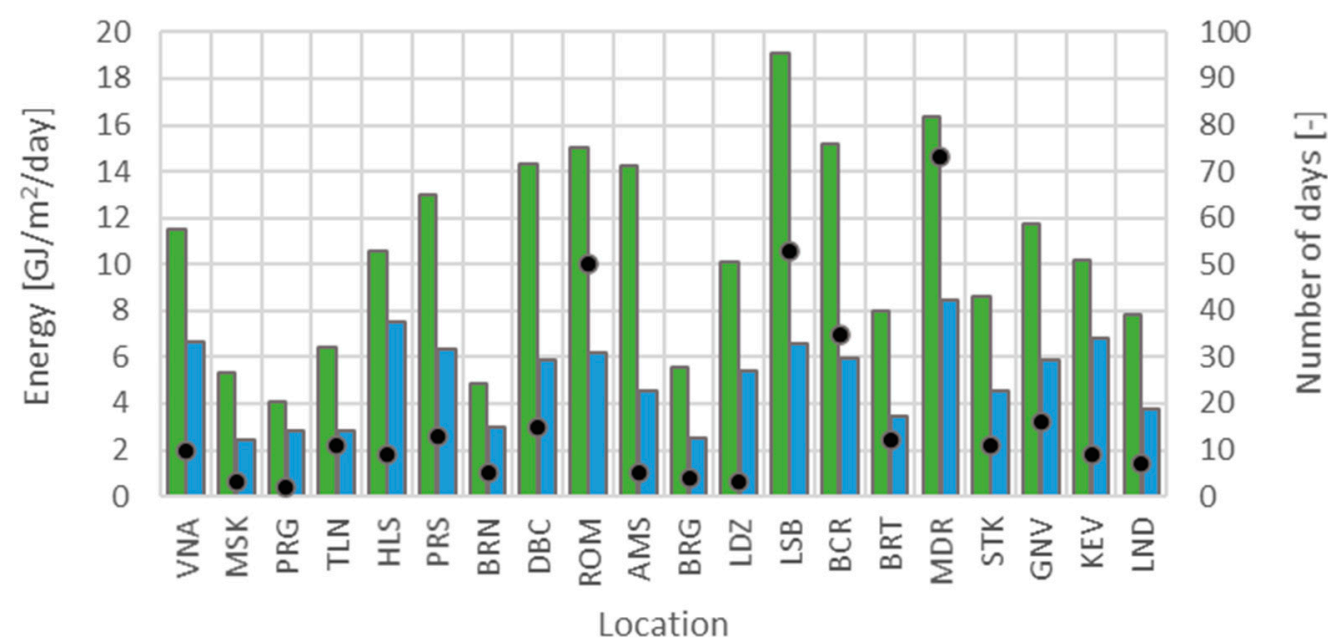

Figure 7. Daily maximum and average values of the solar energy to be absorbed in the PCM layer and number of overheating days.

Due to the stated goal of the PCM layer design, which was protection from overheating over $80^{\circ} \mathrm{C}$, suitable paraffin wax was selected. Based on the properties of the selected material (RT80HC) - density of $880 \mathrm{~kg} / \mathrm{m}^{3}$, and latent heat of $220 \mathrm{~kJ} / \mathrm{kg}$, and a phase change temperature range between $70{ }^{\circ} \mathrm{C}$ and $85{ }^{\circ} \mathrm{C}$ - the average daily value of the solar energy that should be stored in the material as well as its weight and thickness was calculated (Figure 8). The obtained values of the layer thickness varied from $1.2 \mathrm{~cm}$ for 
Minsk up to $4.4 \mathrm{~cm}$ for Madrid. All values were assumed as possible to be applied from a technological point of view and were used in further calculations. It was assumed that PCM will be applied in a shape stabilized layer. In the case of the En-ActivETICS model, the conductivity of PCM was assumed to be constant in both solid and liquid states. The conductivity of the material was $0.14 \mathrm{~W} / \mathrm{m} \mathrm{K}$, and the material was in a direct thermal contact with the PV panel. The PCM can be used in the form of a metal container, which was proposed by the authors of [10]. The apparent heat capacity was estimated based on the data provided by Rubitherm ${ }^{\circledR}$ (Berlin, Germany) and is described by Equation (5):

$$
C_{e f f}(T)=17,600 T-1,302,400 \quad \text { for } \quad T_{M}<T<T_{S}
$$

Weight of PCM $\quad$ Thicknes of PCM

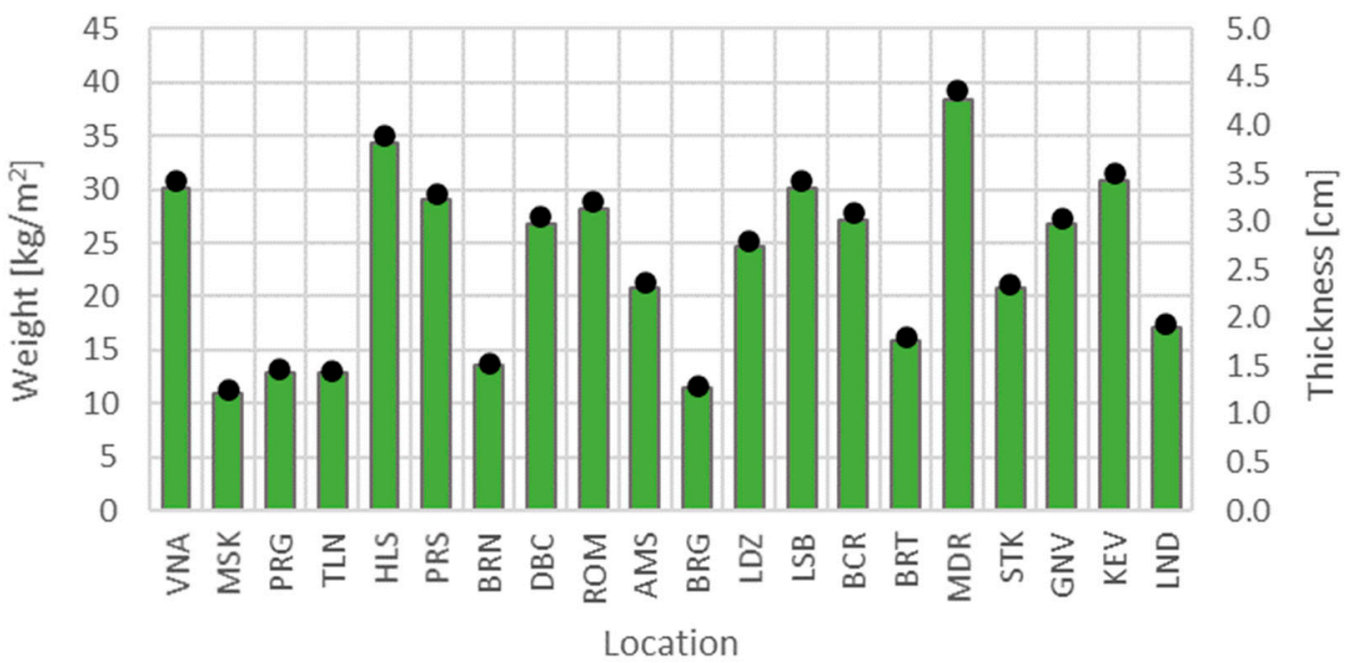

Figure 8. Calculated values of the weight and thickness of the needed PCM layer.

In order to quantitatively assess the effect of the additional layer of PCM, a simulation study was performed for each location, with a designated value of the PCM layer thickness. Two parameters representing the intensity of the PV panel overheating were calculated: the time during which the panel was heated over $80^{\circ} \mathrm{C}$ and the degree-hours of overheating above $80^{\circ} \mathrm{C}$ (DH80), which reflects how often the temperature was exceeded (Figure 9). Comparison of these values, calculated for the case of PV-ETICS and En-ActivETICS, showed that for almost all locations the problem of overheating above $80^{\circ} \mathrm{C}$ was eliminated by the additional layer of PCM, and its thickness was well suited for the climatic conditions. The highest values of $\mathrm{t} 80$ and DH80 parameters for En-ActivETICS were obtained for Madrid. Nevertheless, even in this case, the time of overheating was decreased by $85 \%$. For 13 locations, overheating was eliminated, while for the remaining seven locations, the t80 parameter was lower than $5 \mathrm{~h}$.

The final confirmation of the proper design of the PCM layer was done through the comparison of the values of the maximum temperature of the PV panel in the case of PVETICS and En-ActivETICS (Figure 10). For all locations, the temperature was significantly decreased (for 15 locations, by more than $9{ }^{\circ} \mathrm{C}$ ), and for all locations the maximum value did not exceed $85^{\circ} \mathrm{C}$, which proved that the application of the PCM layer was a good solution for the protection of the PV panel from degradation due to overheating. 


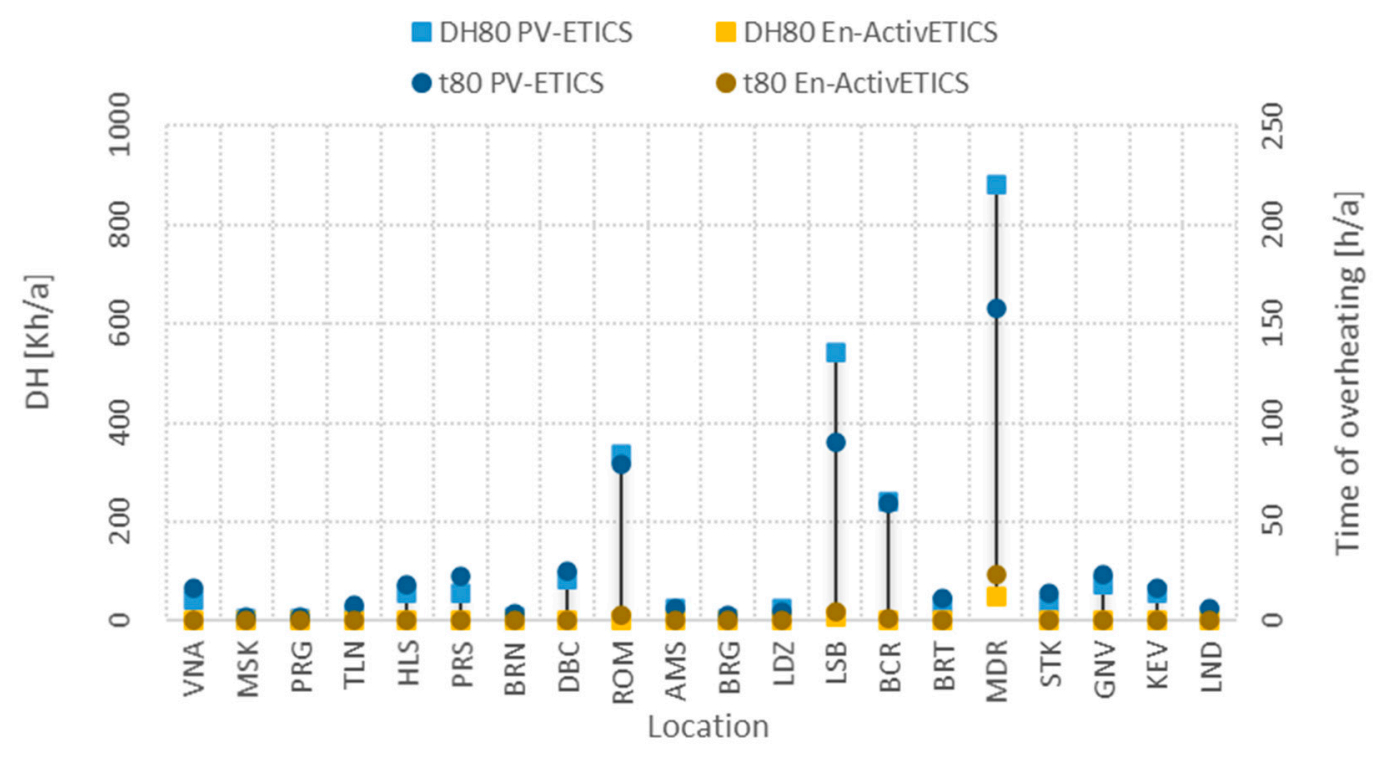

Figure 9. Calculated values of the $t 80$ and degree hours (DH80) parameters for ETICS and PV-ETICS.

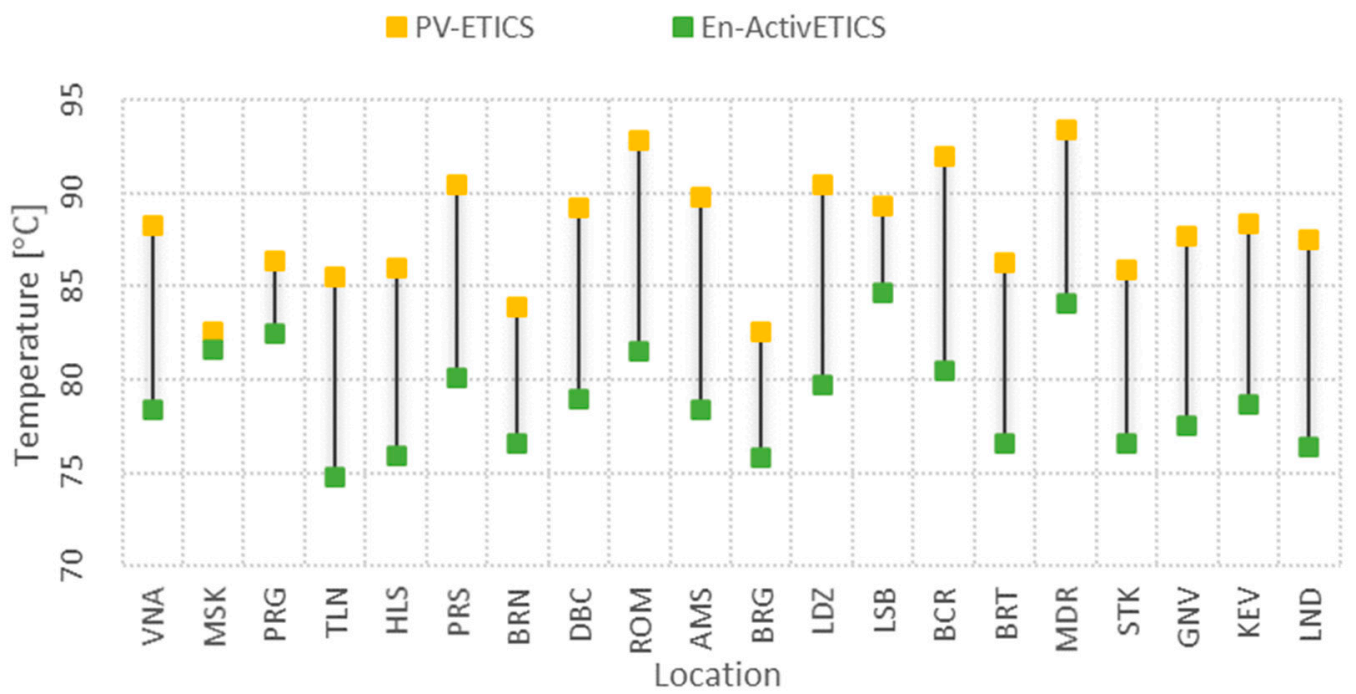

Figure 10. Comparison of the maximum values of the PV temperature in the case of PV-ETICS and En-ActivETICS.

\section{Conclusions}

The results of numerical analyses presented in the paper confirmed the risk of destructive overheating, which can appear on PV panels combined with external thermal insulation (PV-ETICS). Regardless of the location within Europe, the potential for electricity generation in the vertical configuration of PV panels is similar. Based on the initial analyses, it was revealed that, regardless of the building location, the temperature of PV elements exceeded $80^{\circ} \mathrm{C}$. Moreover, for some specific locations in the south of Europe, the overheating is much more serious, with temperature above $85^{\circ} \mathrm{C}$, which can cause faster degradation and decrease the overall performance of electricity production over time.

For the improvement of system durability and to protect the panels against the ageing effect caused by temperatures above $85^{\circ} \mathrm{C}$, a modification of the system was proposed. The proposed idea was the thermal activation of the adjacent layer by phase change material application. A dynamic simulation with a coupled power and heat flow model, including latent heat storage, was used. The obtained results show that the amount of PCM that should be applied depends on the location and varies between 1.0 and $4.5 \mathrm{~cm}$. These results seem to be reasonable considering the total weight of the system. On the other hand, the 
proper design of the PCM layer regarding mechanical stability and thermal performance is a key issue for further investigation. Application of the encapsulated technology will increase the total thickness of the layer, resulting in significant overestimation.

The final analyses for the case with the PCM layer applied in direct thermal contact with the PV panel (EN-ActivETICS) confirmed the correctness of the previous assessment. Due to the latent heat storage of solar energy in peak hours, the maximum temperature does not exceed $85^{\circ} \mathrm{C}$. This condition should lead to the safety and long-term usage of the photovoltaic system. On the other hand, it should be noted that the PCM layer can change its chemical properties over time. Moreover, the tightness of the cover layer is the weakest point of the system, and the risk of material leakage exists. Therefore, the overall thermal performance can change in time, and further full-scale and long-term measurements are necessary to confirm the overall performance of En-ActivETICS.

Author Contributions: Conceptualization, D.H., A.W.; methodology-heat transfer, D.H., A.W.; methodology-power flow, D.H., D.K.; numerical analyses, A.W.; formal analysis, D.H., A.W.; investigation, D.H., A.W., D.K., S.I., T.K., Z.Š.; data curation, A.W.; writing—original draft preparation, D.H., A.W., D.K.; writing-review and editing, S.I., T.K., Z.Š.; visualization, A.W.; supervision, D.H. All authors have read and agreed to the published version of the manuscript.

Funding: This research was supported by the project En-ActivETICS: in a framework of M-ERA.NET by ETAG (grant No. 3-4/MOBERA1719029), NCBiR (grant No. M-ERA.NET2/2018/2/2019) and SAS (grant No. M-ERA.NET 2/2018/786/En-ActivETICS), by the Estonian Centre of Excellence ZEBE (grant TK146), by personal research funding (grant PRG483), and by Finest Twins project (grant No. 856602).

Institutional Review Board Statement: Not applicable.

Informed Consent Statement: Not applicable.

Data Availability Statement: Not applicable.

Acknowledgments: The authors would like to thank Dariusz Czarny from Sto Corp. for his valuable advice and support.

Conflicts of Interest: The authors declare no conflict of interest. The funders had no role in the design of the study; in the collection, analyses, or interpretation of the data; in the writing of the manuscript, or in the decision to publish the results.

\section{References}

1. Tripathy, M.; Sadhu, P.K.; Panda, S.K. A critical review on building integrated photovoltaic products and their applications. Renew. Sustain. Energy Rev. 2016, 61, 451-465. [CrossRef]

2. Knera, D.; Heim, D. Application of a BIPV to cover net energy use of the adjacent office room. Manag. Environ. Qual. Int. J. 2016, 27, 649-662. [CrossRef]

3. Zhou, C.; Liang, R.; Zhang, J.; Riaz, A. Experimental Study on Dynamic Thermal Response of Building Attached Photovoltaic (BAPV) Curtain Wall System. Procedia Eng. 2017, 205, 314-320. [CrossRef]

4. Bigaila, E.; Athienitis, A.K. Modeling and simulation of a photovoltaic/thermal air collector assisting a façade integrated small scale heat pump with radiant PCM panel. Energy Build. 2017, 149, 298-309. [CrossRef]

5. Biyik, E.; Araz, M.; Hepbasli, A.; Shahrestani, M.; Yao, R.; Shao, L.; Essah, E.; Oliveira, A.C.; del Caño, T.; Rico, E.; et al. A key review of building integrated photovoltaic (BIPV) systems. Eng. Sci. Technol. Int. J. 2017, 20, 833-858. [CrossRef]

6. Shukla, A.K.; Sudhakar, K.; Baredar, P. Recent advancement in BIPV product technologies: A review. Energy Build. 2017, 140, 188-195. [CrossRef]

7. Chwieduk, B.; Chwieduk, D. Analysis of operation and energy performance of a heat pump driven by a PV system for space heating of a single family house in polish conditions. Renew. Energy 2020, 165, 117-126. [CrossRef]

8. Asaee, S.R.; Nikoofard, S.; Ugursal, V.I.; Beausoleil-Morrison, I. Techno-economic assessment of photovoltaic (PV) and building integrated photovoltaic/thermal (BIPV/T) system retrofits in the Canadian housing stock. Energy Build. 2017, 152, 667-679. [CrossRef]

9. Weerasinghe, R.P.N.P.; Yang, R.J.; Wakefield, R.; Too, E.; Le, T.; Corkish, R.; Chen, S.; Wang, C. Economic viability of building integrated photovoltaics: A review of forty-five (45) non-domestic buildings in twelve (12) western countries. Renew. Sustain. Energy Rev. 2021, 137, 110622. [CrossRef] 
10. Heim, D.; Chodak, I.; Ilomets, S.; Knera, D.; Wieprzkowicz, A.; Kalamees, T. The integration of selected technology to energy activated ETICS-Theoretical approach. In Proceedings of the 12th Nordic Symposium on Building Physics (NSB 2020), Tallinn, Estonia, 6-9 September 2020; (E3S Web of Conferences). Kurnitski, J., Kalamees, T., Eds.; EDP Sciences: Les Ulis, France, 2020; Volume 172, p. 21004.

11. Ilomets, S.; Kalamees, T. Case-study analysis on hygrothermal performance of ETICS on concrete wall after low-budget energy renovation. In Proceedings of the Thermal Performance of the Exterior Envelopes of Whole Buildings-12th International Conference, Clearwater, FL, USA, 1-5 December 2013; ASHRAE: Atlanta, GA, USA, 2013.

12. Ilomets, S.; Heim, D.; Chodak, I.; Czarny, D.; Kalamees, T. A method to develop energy activated ETICS. In Proceedings of the 12th Nordic Symposium on Building Physics (NSB 2020), Tallinn, Estonia, 6-9 September 2020; (E3S Web of Conferences). Kurnitski, J., Kalamees, T., Eds.; EDP Sciences: Les Ulis, France, 2020; Volume 172, p. 21006.

13. Heim, D. The simultaneous effect of the operating temperature and solar radiation on the efficiency of photovoltaic panels. Arch. Civ. Eng. 2011, 57, 261-274. [CrossRef]

14. Wang, H.; Wang, A.; Yang, H.; Huang, J. Study on the thermal stress distribution of crystalline silicon solar cells in BIPV. Energy Procedia 2016, 88, 429-435. [CrossRef]

15. Pandian, A.; Bansal, K.; Thiruvadigal, D.J.; Sakthivel, S. Fire Hazards and Overheating Caused by Shading Faults on Photo Voltaic Solar Panel. Fire Technol. 2016, 52, 349-364. [CrossRef]

16. Omazic, A.; Oreski, G.; Halwachs, M.; Eder, G.C.; Hirschl, C.; Neumaier, L.; Pinter, G.; Erceg, M. Relation between degradation of polymeric components in crystalline silicon PV module and climatic conditions: A literature review. Sol. Energy Mater. Sol. Cells 2019, 192, 123-133. [CrossRef]

17. Park, N.C.; Oh, W.W.; Kim, D.H. Effect of Temperature and Humidity on the Degradation Rate of Multicrystalline Silicon Photovoltaic Module. Int. J. Photoenergy 2013, 2013, 925280. [CrossRef]

18. Kurtz, S.; Whitfield, K.; TamizhMani, G.; Koehl, M.; Miller, D.; Joyce, J.; Wohlgemuth, J.; Bosco, N.; Kempe, M.; Zgonena, T. Evaluation of high-temperature exposure of photovoltaic modules. Prog. Photovolt. Res. Appl. 2011, 19, 954-965. [CrossRef]

19. Mehta, S.; Biederman, S.; Shivkumar, S. Thermal degradation of foamed polystyrene. J. Mater. Sci. 1995, 30, 2944-2949. [CrossRef]

20. Nowoświat, A.; Krause, P.; Miros, A. Properties of expanded graphite polystyrene damaged by the impact of solar radiation. J. Build. Eng. 2021, 34, 101920. [CrossRef]

21. Bayrak, F.; Oztop, H.F.; Selimefendigil, F. Experimental study for the application of different cooling techniques in photovoltaic (PV) panels. Energy Convers. Manag. 2020, 212, 112789. [CrossRef]

22. Tao, M.; Zhenpeng, L.; Jiaxin, Z. Photovoltaic panel integrated with phase change materials (PV-PCM): Technology overview and materials selection. Renew. Sustain. Energy Rev. 2019, 116, 109406.

23. Heim, D.; Wieprzkowicz, A. Attenuation of Temperature Fluctuations on an External Surface of the Wall by a Phase Change Material-Activated Layer. Appl. Sci. 2017, 8, 11. [CrossRef]

24. Pournami, M.C.; Sreenath, B.; Zachariah, R. A comprehensive review on the recent advancements in PV panel cooling techniques using phase changing materials. In Proceedings of the 2017 IEEE International Conference on Intelligent Techniques in Control, Optimization and Signal Processing (INCOS), Piscataway, NJ, USA, 23-25 March 2017; pp. 1-6.

25. Hasan, A.; McCormack, S.J.; Huang, M.J.; Sarwar, J.; Norton, B. Increased photovoltaic performance through temperature regulation by phase change materials: Materials comparison in different climates. Sol. Energy 2015, 115, 264-276. [CrossRef]

26. Clarke, J. Integrative modelling methods. Response 2001, 90, 22-63.

27. Clarke, J.A.; Kelly, N.J. Integrating power flow modelling with building simulation. Energy Build. 2001, 33, 333-340. [CrossRef]

28. Mottillo, M.; Beausoleil-Morrison, I.; Couture, L.; Poissant, Y. A comparison and validation of two photovoltaic models. In Proceedings of the Canadian Solar Buildings Conference, Montreal, QC, Canada, 20-24 August 2006.

29. Thevenard, D. Review and recommendations for improving the modelling of building integrated photovoltaic systems. In Proceedings of the Ninth International IBPSA Conference, Montréal, QC, Canada, 15-18 August 2005; pp. 1221-1228.

30. Heim, D.; Wieprzkowicz, A. Positioning of an isothermal heat storage layer in a building wall exposed to the external environment. J. Build. Perform. Simul. 2016, 9, 542-554. [CrossRef]

31. Heim, D. Phase-Change Material Modeling within Whole Building Dynamic Simulation. ASHRAE Trans. 2006, 112, 518-525.

32. Clarke, J.A.; Kelly, N.J.; Tang, D. A Review of ESP-r's Flexible Solution Approach and its Application to Prospective Technical Domain Developments. Adv. Build. Energy Res. 2007, 1, 227-247. [CrossRef]

33. Ascencio-Vásquez, J.; Brecl, K.; Topič, M. Methodology of Köppen-Geiger-Photovoltaic climate classification and implications to worldwide mapping of PV system performance. Sol. Energy 2019, 191, 672-685. [CrossRef]

34. Pernigotto, G.; Walsh, A.; Gasparella, A.; Hensen, J.L.M. Clustering of European Climates and Representative Climate Identification for Building Energy Simulation Analyses. In Proceedings of the 16th IBPSA Conference, Rome, Italy, 2-4 September 2019; pp. $4833-4840$.

35. EnergyPlus. Weather Data. Available online: https://www.energyplus.net/weather (accessed on 21 March 2021). 